\title{
Grandparents Raising Grandchildren: Custody Options ${ }^{1}$
}

Millie Ferrer-Chancy, Larry Forthun, and Angela Falcone ${ }^{2}$

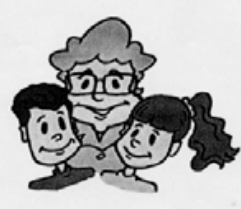

Goal: To provide grandparents with information about Florida's legal system as it relates to grandparents raising grandchildren.

\section{CUSTODY OPTIONS}

In caring for grandchildren, grandparents have several custody options. To decide which options match your needs, you must become familiar with legal terms. Courts classify families in two ways:

- families with dependent children

- families without dependent children

A family with a dependent child receives ongoing supervision by a case worker from a local Community-Based Care (CBC) provider. A child can become dependent on the State if $s$ /he has been abused, neglected, or abandoned by a parent. Dependent children are also referred to as "adjudicated dependent."

Families without dependent children do not receive ongoing supervision by a CBC provider. The custody options available for families without dependent children are not the same as those with dependent children. In Tables 1 and 2 of this publication, you will find specifics of these custody options: Table 1 outlines options for families without dependent children, whereas Table 2 outlines custody options for families with dependent children.

After familiarizing yourself with the various custody options described in Tables 1 and 2, review the situation scenarios that follow and decide which custody option would be best for that grandparent or other relative.

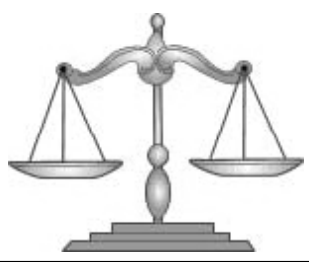

1. This document is FCS2189, one of a series of the Department of Family, Youth and Community Sciences, Florida Cooperative Extension Service, Institute of Food and Agricultural Sciences (IFAS), University of Florida. First published: December 2002. Revised: August 2009. Please visit the EDIS Web site at http://edis.ifas.ufl.edu.

2. Millie Ferrer-Chancy, Ph.D., interim dean, Florida Cooperative Extension Service, University of Florida; Larry F. Forthun, Ph.D., assistant professor, Department of Family, Youth and Community Sciences; Angela Falcone, former FYCS graduate student; Institute of Food and Agricultural Sciences, University of Florida, Gainesville, FL 32611. 
Table 1. Custody Options for Non-Dependent Children (not under supervision of the Department of Children and Families)

\begin{tabular}{|c|c|c|c|c|}
\hline & Description & Grandparent's Rights & Parent's Rights & Best Choice If... \\
\hline $\begin{array}{l}\text { Informal/Physical } \\
\text { Custody }\end{array}$ & $\begin{array}{l}\text { - Most common } \\
\text { - Not considered legal } \\
\text { custody }\end{array}$ & $\begin{array}{l}\text { - Grandparent has no legal right } \\
\text { to make important decisions } \\
\text { for child } \\
\text { - With durable Power of Attorney } \\
\text { from parent, grandparent's } \\
\text { custody is strengthened } \\
\text { - Power of Attorney can be } \\
\text { taken away at any time by the } \\
\text { parent who granted it }\end{array}$ & $\begin{array}{l}\text { - Parents can take child back at } \\
\text { any time } \\
\text { - Parents still have legal rights }\end{array}$ & $\begin{array}{l}\text { - Parent and } \\
\text { grandparent are in } \\
\text { agreement }\end{array}$ \\
\hline $\begin{array}{l}\text { Temporary } \\
\text { Custody }\end{array}$ & $\begin{array}{l}\text { - Legal form of custody } \\
\text { - For a specific length of time, } \\
\text { possibly until age } 18\end{array}$ & $\begin{array}{l}\text { - Grandparent can strengthen } \\
\text { this custody by moving the } \\
\text { case to dependency court if } \\
\text { the parent proves to be unfit } \\
\text { - Custody order determines the } \\
\text { decisions grandparents can } \\
\text { make for the grandchild }\end{array}$ & $\begin{array}{l}\text { Because it is legal custody, } \\
\text { the parent cannot terminate } \\
\text { this custody, only the courts } \\
\text { can revoke this custody }\end{array}$ & $\begin{array}{l}\text { - Grandparent and } \\
\text { parent are in } \\
\text { agreement } \\
\text { - Grandparent is not } \\
\text { trying to strengthen } \\
\text { custody by proving } \\
\text { parent to be unfit }\end{array}$ \\
\hline Guardianship & $\begin{array}{l}\text { - Legal form of custody } \\
\text { - Two types: person and } \\
\text { property (material } \\
\text { belongings) } \\
\text { - Permanent until child is } 18 \\
\text { or court removes } \\
\text { guardianship } \\
\text { - Next to adoption, this is one } \\
\text { of the most secure and } \\
\text { permanent relationships }\end{array}$ & $\begin{array}{l}\text { - Grandparents have all } \\
\text { authority over the child }\end{array}$ & $\begin{array}{l}\text { - Parental rights do not have to } \\
\text { be terminated } \\
\text { - Requires court order to be } \\
\text { changed }\end{array}$ & $\begin{array}{l}\text { - Grandparents } \\
\text { desire long-term } \\
\text { commitment and } \\
\text { want authority to } \\
\text { make decisions }\end{array}$ \\
\hline Adoption & $\begin{array}{l}\text { - Most permanent legal } \\
\text { custody } \\
\text { - Can happen when parent } \\
\text { consents or court has } \\
\text { terminated parental rights }\end{array}$ & $\begin{array}{l}\text { - Grandparents have all } \\
\text { authority over the child } \\
\text { - Grandparents no longer } \\
\text { eligible for State benefits } \\
\text { unless: } \\
\text { o They are income eligible } \\
\text { o The child was adopted } \\
\text { through the State, in which } \\
\text { case the grandparents may } \\
\text { become eligible for an } \\
\text { adoption subsidy }\end{array}$ & - Parents lose their rights & $\begin{array}{l}\text { - Grandparents are } \\
\text { determined to have } \\
\text { the most secure, } \\
\text { permanent custody } \\
\text { for the child } \\
\text { - Parent's rights have } \\
\text { been terminated }\end{array}$ \\
\hline
\end{tabular}


Table 2. Custody Options for Dependent Children (Adjudicated Dependent)

\begin{tabular}{|c|c|c|c|c|}
\hline & Description & Grandparent's Rights & Parent's Rights & Best Choice If... \\
\hline $\begin{array}{l}\text { Court-Ordered } \\
\text { Placement }\end{array}$ & $\begin{array}{l}\text { - Grandparents have physical } \\
\text { custody } \\
\text { - Department of Children and } \\
\text { Families (DCF) mandates } \\
\text { ongoing supervision } \\
\text { - Community-Based Care } \\
\text { (CBC) provider has } \\
\text { supervising authority } \\
\end{array}$ & $\begin{array}{l}\text { - Grandparents can make day- } \\
\text { to-day decision about } \\
\text { grandchild } \\
\text { - Grandparents are provided } \\
\text { with needed services by a } \\
\text { CBC caseworker }\end{array}$ & $\begin{array}{l}\text { - Parent can work on case plan } \\
\text { to get child back } \\
\text { - Parent is provided with } \\
\text { needed services by CBC } \\
\text { caseworker } \\
\text { - Parents will have to sign for } \\
\text { major medical procedures for } \\
\text { the child }\end{array}$ & $\begin{array}{l}\text { - You believe parent } \\
\text { is working hard and } \\
\text { is committed to } \\
\text { following the case } \\
\text { plan to get child } \\
\text { back }\end{array}$ \\
\hline $\begin{array}{l}\text { Temporary Legal } \\
\text { Custody }\end{array}$ & $\begin{array}{l}\text { - Grandparents have court- } \\
\text { ordered legal custody } \\
\text { - DCF mandates ongoing } \\
\text { supervision }\end{array}$ & $\begin{array}{l}\text { - Grandparents can make } \\
\text { important decisions about } \\
\text { grandchild with minimal CBC } \\
\text { supervisions }\end{array}$ & $\begin{array}{l}\text { - Parent has visitation rights } \\
\text { - Parent can work on case plan } \\
\text { to get child back } \\
\text { - Parents will have to sign for } \\
\text { major medical procedures for } \\
\text { the child }\end{array}$ & $\begin{array}{l}\text { - You are uncertain if } \\
\text { parent will follow } \\
\text { through with } \\
\text { required case plan }\end{array}$ \\
\hline $\begin{array}{l}\text { Long-Term Legal } \\
\text { Custody }\end{array}$ & $\begin{array}{l}\text { - Option granted after } 6 \\
\text { months of CBC supervision } \\
\text { with temporary legal } \\
\text { custody } \\
\text { - More secure and } \\
\text { permanent arrangement } \\
\text { than placement or } \\
\text { temporary legal custody }\end{array}$ & $\begin{array}{l}\text { - Grandparents have full } \\
\text { authority over grandchild }\end{array}$ & $\begin{array}{l}\text { - Parents can regain custody if } \\
\text { they can prove that: } \\
\text { oThe situation that has } \\
\text { caused them to lose } \\
\text { custody has changed } \\
\text { oLiving with parents is best } \\
\text { for the child }\end{array}$ & $\begin{array}{l}\text { - Parent consents to } \\
\text { grandparents } \\
\text { having long-term } \\
\text { legal custody } \\
\text { - Parent's rights have } \\
\text { been terminated } \\
\text { - Parent does not } \\
\text { follow case plan as } \\
\text { instructed }\end{array}$ \\
\hline Adoption & $\begin{array}{l}\text { - Most permanent legal } \\
\text { custody } \\
\text { - Can happen when parent } \\
\text { consents or court has } \\
\text { terminated parental rights }\end{array}$ & $\begin{array}{l}\text { - Grandparents have all } \\
\text { authority over the child. } \\
\text { - Grandparents no longer } \\
\text { eligible for State benefits } \\
\text { unless: } \\
\text { o They are income eligible } \\
\text { o The child was adopted } \\
\text { through the State, in which } \\
\text { case the grandparents may } \\
\text { become eligible for an } \\
\text { adoption subsidy }\end{array}$ & - Parents lose their rights & $\begin{array}{l}\text { - Grandparents are } \\
\text { determined to have } \\
\text { the most secure, } \\
\text { permanent custody } \\
\text { for the child } \\
\text { - Parent's rights have } \\
\text { been terminated }\end{array}$ \\
\hline
\end{tabular}




\section{$\underline{\text { Situation Scenarios }}$}

1. After taking care of her grandchild for over three years, Mrs. Johnson wants to secure the most permanent custody for her grandchild. What is her best option?

2. Mrs. Simmons' grandchildren just moved in with her due to parental drug abuse. She is uncertain that her daughter will be willing to follow her case plan to get her children back. What option does Mrs. Simmons have?

3. Mr. and Mrs. Garcia agree to take care of their grandchildren while their parents re-establish themselves in a new location. What is the best custody option?

4. Mrs. Smith has been caring for her grandchildren for over six months. During that time, the family has been supervised by a DCF caseworker. Mrs. Smith wants to seek a more secure and permanent arrangement because her daughter is not following her case plan. What options are open to Mrs. Smith?

(See bottom corner of this page for possible answers)

\section{Where to Find Help About Legal Issues}

If you need additional information about legal matters, contact the following services.

Lawyer Referral Service: This is a public service of the Florida Bar Association. By calling 1-800-342-8060, you will be referred to a lawyer. The lawyer will provide an initial 30-minute consultation for free or a small fee.
- Attorney: Look in the yellow pages for one who specializes in family law.

- Department of Children and Families: If you call 1-800-342-8025, you can find out about the services available in your community.

- Family Mediation: The number for your area is found in the blue pages (government pages) of your phone book. Look under Court Administrator's office.

- Department of Social Services: The number for your area is found in the blue pages of your phone book under Social Services.

\section{FOR MORE LEGAL INFORMATION}

Florida Kinship Center-Kinship Care Warmline A statewide emotional support line for kinship caregivers in Florida. 1-800-640-6444 http://www.flkin.org/

Generations United, Grandfamilies State Law and Policy Resource Center http://www.grandfamilies.org/

\section{References}

AARP Grandparent Toolkit http://www.aarp.org/family/grandparenting/articles/gr andcare toolkit.html

Florida Kinship Center (2008) Kinship Care Legal Handbook. University of South Florida School of Social Work, Tampa, FL. Retrieved from: http://www.flkin.org/Legal000001.asp 